\title{
Exploring Roles, Requirements and Rewards in French and English-Canadian Business Development Job Postings
}

\author{
Normand Turgeon ${ }^{1}$ \\ ${ }^{1}$ Department of marketing, HEC Montréal, Montreal, Canada \\ Correspondence: Normand Turgeon, Department of Marketing, HEC Montréal, 3000 chemin de la Côte \\ Ste-Catherine, Montreal, QC, H3T 2A7, Canada. Tel: 1-514-340-6424. E-mail: normand.turgeon@hec.ca
}

Received: November 18, 2015

Accepted: December 26, 2015 Online Published: January 28, 2016

doi:10.5539/ijms.v8n1p33

URL: http://dx.doi.org/10.5539/ijms.v8n1p33

\begin{abstract}
This paper examines the content of job postings in business development, a new career path proliferating around the world. Content analysis of 48 advertisements, half of which appeared in French and the other half in English, was conducted, and the results regarding roles, requirements rewards are presented according to two languages of work, the cultural expression mode of organizations. We find that business developers are heavily involved in implementing commercialization activities, mainly in the joint marketing-sales process. To a lesser extent, they also assume the roles of analysis, planning and control of these activities. Concerning the impact of cultural belonging, significant differences were noted for criteria associated with all three of the categories studied. More knowledge of business development is needed to better guide marketing and sales instructors, and to satisfy the needs of organizations seeking these commercialization professionals.
\end{abstract}

Keywords: business development jobs, job posting description, roles, requirements, rewards, language of recruitment, content analysis

\section{Introduction}

The study of the content of job postings in business development is important and informative in many respects. For instance, academics have an intrinsic need to better understand job requirements and share their findings (Pefanis, Schlee, \& Harich, 2010; Diamond et al., 2014). A second motivation is assurance of learning, used as a standard in the AACSB's accreditation process (LaFleur, Babin, \& Lopez, 2009), the results of such research help guide the formulation and refinement of marketing and sales study programs. Finally, one must also consider competition between institutions of higher education (Wildasky, 2010), notably to ensure that alumni can access quality jobs throughout their career. Indeed, enabling marketing and sales graduates to obtain better jobs can positively influence business schools' international rankings (e.g. in lists compiled by the Financial Times, The Economist, and US News \& World Report) and ultimately grant universities preferred access to the best candidates during recruitment campaigns.

This paper analyzes job postings on the Web, which serves as a communication tool for recruitment in business development. The first objective is to identify signals organizations convey in their job postings to attract the best business developers. Business development job creation originates in businesses with different cultural universes, a factor whose impact is postulated as significant (Fyrpil, 2012) and is hence worth studying. Specifically, we analyze the content of three types of information usually contained in these postings, namely roles, requirements, and rewards, according to the language of recruitment of the posting, used as a proxy for language of work (Jameson, 2007).

\section{Conceptual Background}

\subsection{Roles, or What Employers Expect}

Sorensen's (2012) definition of the role of business developers is being increasingly adopted: "Business development refers to the tasks and processes concerning analytical preparation of potential growth opportunities, the support and monitoring of the implementation of growth opportunities, but does not include decisions on strategy and implementation of growth opportunities". For Sorensen (2014), business development is practiced only in the case of "non-trivial" but "non-strategic" growth pursuit at the firm level. The results of Eidhoff and Poelzl's (2014) exploratory research among 16 business developers in a B2B context in Germany reflect this 
vision: the two main tasks mentioned (eight times each, the maximum observed) was "developing businesses and identifying growth opportunities" and "merger and acquisition processes".

In contrast, Bussgang et al. (2013) stipulate that a business developer: “...is a strategist, deal maker, and brand ambassador, all rolled into one" (p. 1). The business developer is therefore part of the strategic process and may engage in sales to both internal and external customers of the organization, as a brand ambassador. This vision is consistent with the nomenclature of the main functions inventoried among Canadian businesses operating in the IT sector, compiled by Davis and Sun (2006). They identified four tasks mentioned by over $50 \%$ of organizations surveyed: "identify or create opportunity", "develop or maintain partnership", "follow-up with customers", and "new product/process/solution development".

These diverse conceptual descriptions of business development and the results of surveys on these practices validate Pollack's (2012) question: “What, exactly, is business development?" Hence the first research question:

RQ1: What are the roles of business developers across industries and sectors?

\subsection{Requirements, or What It Takes to Get the Job}

Numerous studies have identified sets of skills, capabilities or attributes for a job either in marketing (Finch, Nadeau, \& O'Reilly, 2012), sales (Diamond et al., 2014) or sales management (Powers, Jennings, \& DeCarlo, 2014). These contributions are important, but candidates for business development jobs might also need different proficiencies to satisfy employers' requirements. Eidhoff \& Poelzl (2014) divide their findings on this subject into two categories: qualifications and competences. Regarding the first category, most respondents have an advanced education, including in specialties such as management, engineering, marketing, sales, finance, law, accounting and procurement. Few respondents completed graduate studies, and only one held an MBA. Interestingly, a degree in business is not the only key to accessing a career in business development. In fact, having an education in a field other than business might be more desirable because candidates can understand potential clients' sophisticated technical needs. This requirement (understand clients' needs) was mentioned by many respondents (42.3\%) in Davis \& Sun's (2006) study. Their list of skills and attributes, which was rather long (26 in total), included elements such as communication, (the most important), "creative thinking, dreamer", "listening", "technical/ analytical", and "honest". Principal component analysis of the elements in the list points to two dimensions: the first on the "resourcefulness-likeability" axis and the second on the "engagement-knowledge" axis. This result parallels the list of Eidhoff \& Poelzl (2014), which includes the attributes "methodological and analytical skills", "understanding markets and customers", "creativity", "potential to cope with frustration", "ability to take decisions", and "working experience".

Janovics \& Christiansen (2003) explored business developers' proficiencies from a different angle by trying to associate personality traits with two prominent roles in business development: ideation and implementation. Four traits are proposed-"innovation", "efficacy", "independence", and "methodical"- to define these two roles. The authors also produced a profile for each role: consistent with the hypotheses, although only partly significant, the scores associated with ideation are higher for the traits "innovation", "efficacy", and "independence", and lower for "methodical". The opposite results apply to the "implementation" role.

Collectively, these studies underline the existence of a wide variety of assets, some of which areassociated with being a likable person, and others with being technically and commercially competent. Although the skills and attributes identified are not necessarily exclusive to business development, the combination of them might be, hence the second research question:

RQ2: What set of requirements do organizations mention in their job postings aimed at business developers?

\subsection{Rewards, or What Motivate}

Hulbert, Caponand, \& Percy (2003) argue that human resources are instrumental to the success of marketing strategies. The intellectual capital of organizations may be a sustainable competitive advantage if used well. By putting in place interfaces between marketing and human resources, sales and human resources, and marketing and sales, firms can effectively triangulate the efforts of each of these functions.

A business development-human resources interface could thus enhance commercialization efforts. One of the goals of this interface is to motivate the staff assigned to this task. Human resources managers can consider five sources of motivation at work (referred to as the total reward strategy) (Giancola, 2009): compensation, benefits, work-life balance, performance and recognition, and development and career opportunities. According to Feldman, Bearden, \& Hardesty (2006), providing information about each of these motivators in job postings is crucial. In their study, subjects who received specific information on the company, job and work contexts rated perceived appropriateness of advertised jobs, perceived truthfulness of the posting, attitude toward the posting, 
and attitude toward the company more highly. In addition, the more complete the contents of the posting, the more it was considered credible and the more it fostered a positive attitude toward the posting and the organization. Hence the third research question:

RQ3: What elements of the total reward strategy do organizations use when drafting job postings to recruit business development employees?

\subsection{Impact of Language of Recruitment, a Proxy of Language of Work}

Another fertile research avenue concerns possible differences in signals used in postings, related to roles, requirements and rewards, by language of recruitment, which serves as a proxy for language of work.

Regarding roles, Boroditsky (2010) argues that language profoundly shapes how we construct reality. This should also be true of language of work, the mode of cultural expression of organizations. For Erez (2010), the presence of culture as a moderating variable is necessary because it affects the job design, a construct defined as: "the structure, content, and configuration of a person's tasks and roles" (p.389). Hence, language of work, which dictates language of recruitment, should influence the creation of job postings in business development.

Concerning requirements, Ahmed \& Crossman (2008) conclude that factors of employability differ according to the cultural contexts of work. They maintain that factors such as "a graduate's possession of the skills, knowledge, attitudes, and commercial understanding" (p.61) are elements that let organizations judge the potential efficacy of a future employee. They cite the conclusions of the cross-cultural research by Harvey \& Bowers-Brown (2004), who identified variance in necessary attributes depending on whether graduates come from US, Canada, Finland, Denmark, South Africa, Australia or New Zealand. Ahmed \& Crossman (2008) contend that better knowledge of the requirements stipulated by employers belonging to different cultures can help three target audiences: 1) graduates who want to practice their profession in different geographical locations; 2) faculty of educational institutions who prepare students to face a globalized labor market and; 3) organizations themselves, which can determine the exact profile of desirable candidates based on the work to be performed, anywhere in the world.

Lastly, research also tends to demonstrate the effect of cultural context on total compensation or rewards offered to employees (Schuler \& Rogovsky, 1998). Gray \& Benson (2003) examined small business development centers, and conclude that female executives are compensated significantly less than male executives, when education, tenure, size, performance and organizational affiliation are held constant. These results corroborate those of Dreher \& Cox (1996), who find significant differences in compensation between black and white employees and between men and women. One explanation for these differences is linked to Balkin \& Gomez-Mejia's contingency theory (1987), which states that compensation strategies depend on organizational and environmental characteristics. Lang (1986) studied how language (verbal and non-verbal) is used as an element of discrimination between black and white people and between men and women. He posits that not belonging to a group that uses dominant language codes, in this case white men, represents a transaction cost to overcome, a form of economic discrimination that would explain differences in compensation. Therefore, reward signals that appear in job postings may reflect the language conditions of desirable candidates.

The above arguments imply that language of recruitment, used as a proxy for language of work, may affect the content of a business developer job, hence the fourth research question:

RQ4: Do roles, requirements and rewards conveyed in business development job postings vary among organizations with different modes of cultural expression?

\section{Research Design}

\subsection{Research Object and Context}

Owing to their growing popularity in the job market, electronic job postings have been investigated extensively (Pefanis, Schlee, \& Harich, 2010; Diamond et al., 2014). The postings retained in this research targeted a population of potential employees who identified primarily with one of the two official languages of Canada. This particular research context was deliberately selected to avoid undesirable and elusive effects of concomitant variables (e.g., unemployment, sexism, ageism) on the results.

The province of Québec represented both a valid and practical choice. Its effective recognition as a nation has been politically sanctioned (Harper, 2006), backed by the argument of the undeniable presence of the "French fact" in the English-speaking sea of Canada. The Hofstede Center (2014) reports that "Compared with their Anglophone counterparts, French-Canadians can be more formal, hierarchical, moderately relationship focused, and more emotionally expressive." Because job offers in business development are available in the two official 
languages in this province, comparison according to these two distinct linguistic blocks, which often compete in the business world, is fertile ground for this quasi-experiment.

\subsection{Description of the Sample}

Job offers were gathered from the website ca.indeed.com. This metasearch engine notably compiles postings published on a multitude of websites (sites of companies, employment agencies and specialized or general job search firms). The search for job offers was conducted over five weeks. We used the following criterion: the precise expression "développement des affaires" (French for business development) or "business development" had to be stated in the title of the posting.

We initially collected 117 job postings. After verification and elimination of duplicates, 100 postings were retained: 60 in French and 40 in English. Twenty-four of these postings were chosen at random for each language. The coding chart to categorize the content of the postings according to the three research themes was produced first in French and then in English. The chart contained three sections: 1) requirements, divided into five subgroups: experience, hard skills, soft skills, knowledge areasand training required; 2) roles, divided into four subgroups, corresponding to the managerial cycle: analysis, planning, implementation, and control; and 3) rewards, divided into four subgroups: compensation and other benefits, training and support, work environment and organizational assets. Two bilingual research assistants, human resources management graduates, participated in the analysis, together with the main researcher. A pretest of the two charts was done for six job postings per language, selected at random, and the results are conclusive, with an inter-judge agreement score of .744 (Krippendorff, 1980) and a composite reliability coefficient of .853 (Shoemaker, 2003; Holsti, 1969). The final data base was compiled after consensus was reached in cases of disagreement between the coders.

\section{Findings}

\subsection{Differences in Roles}

The most important role of business developers (see Table 1) is by far that of implementation, with 193 mentions of related criteria in the English and French postings in the sample. The common roles across postings are linked to sales, specifically prospecting, sales/customer follow-up, sales/solicitation/representation, and external and internal networking. Overall, business development roles are thus strongly oriented towards sales. The second most important category is linked to control, notably for the tasks of supervision, performance management and report production. Roles related to planning and analysises are fewer, but are nonetheless important in business developers' daily tasks.

The results indicate few differences between the roles of business developers in English versus French postings. Significant differences were found only for the criteria "sales/solicitation/representation", "administrative assistance", and "organization of work". The number of postings that clearly highlighted the sales role is higher in the English sample than in the French sample, whereas the opposite is true for the roles of administrative assistance and organization of work. Given the consistent distribution of postings according to level of employment (entry, intermediate and senior) between the two samples, these differences come from the content of the job postings as such, therefore from the conceptualization of the role of business development by these two cultures.

\subsection{Differences in Requirements}

The three most important categories are, in order, general competences, experience and knowledge (see Table 2). Across all the categories, for English and French postings combined, the criterion "personality traits" was most frequent. It is followed closely by the criteria "sales experience", "knowledge of sales/networking", and in technical skills, "fully bilingual". For the latter criterion, we observed a significant difference between French and English postings. The same is true for the criterion "proficiency in a second language" another statistically significant difference. Upon closer analysis, bilingualism is required in most French postings, which explains the lower number of mentions of the criterion "proficiency in a second language". The inverse is seen in the English postings: fewer requirements of total bilingualism — which is to be expected because candidates are expected to be fluent in English if they apply for the job - but more requirements for knowledge of a second language, in this case French. 
Table 1. Roles mentioned in job postings

\begin{tabular}{|c|c|c|c|c|c|}
\hline & & \multirow{2}{*}{$\begin{array}{l}\text { Total } \\
\text { mentions } \\
\text { in postings } \\
(\mathrm{N}=48)\end{array}$} & \multicolumn{2}{|c|}{$\begin{array}{l}\text { Proportion of job } \\
\text { postings with mention }\end{array}$} & \multirow{2}{*}{$\begin{array}{l}\text { Statistical } \\
\text { significance } \\
\mathrm{Z} \text { test, two } \\
\text { tail, } \mathrm{p} \leq .10\end{array}$} \\
\hline & & & $\begin{array}{l}\text { English } \\
(\mathrm{N}=24)\end{array}$ & $\begin{array}{l}\text { French } \\
(\mathrm{N}=24)\end{array}$ & \\
\hline \multirow[t]{4}{*}{ Analysis } & & 23 & & & \\
\hline & Competitive intelligence & 9 & .560 & .440 & .71 \\
\hline & Strategic intelligence & 8 & .625 & .375 & .44 \\
\hline & Market analysis & 6 & .667 & .340 & .38 \\
\hline \multirow[t]{3}{*}{ Planning } & & 40 & & & \\
\hline & Operational planning & 23 & .478 & .522 & .77 \\
\hline & Strategic planning & 17 & .588 & .412 & .36 \\
\hline \multirow[t]{10}{*}{ Implementation } & & 193 & & & \\
\hline & Prospecting & 37 & .486 & .514 & .72 \\
\hline & Sales/client follow-up & 36 & .444 & .556 & .18 \\
\hline & Sales/solicitation/representation & 33 & .606 & .394 & .03 \\
\hline & External networking & 28 & .464 & .536 & .55 \\
\hline & Internal networking & 23 & .458 & .542 & .56 \\
\hline & Qualification/need assessment & 12 & .583 & .417 & .50 \\
\hline & Administrative assistant & 10 & .200 & .800 & .03 \\
\hline & Team organization & 7 & .429 & .571 & .68 \\
\hline & Organization of work & 7 & .143 & .857 & .04 \\
\hline \multirow[t]{5}{*}{ Control } & & 49 & & & \\
\hline & Team/work supervision & 15 & .467 & .533 & .75 \\
\hline & Performance management & 13 & .385 & .615 & .33 \\
\hline & Progress status/sales report & 12 & .583 & .417 & .50 \\
\hline & Process improvement & 9 & .556 & .444 & .71 \\
\hline
\end{tabular}

Another notable significant difference is that the requirement of experience in marketing and business development is much lower for French speakers, as is the number of mentions of the criteria "personality traits", "interpersonal relations" and "communication". One significant criterion that deserves particular attention is that a degree is not required in 10 of the 24 English postings, compared with only four of the 24 French postings.

\subsection{Differences in Rewards}

Of the four categories related to the total rewards strategy, the work environment ranks first in terms of number of mentions, followed closely by compensation and other benefits (see Table 3). Indeed, in the category compensation and benefits the criterion "commission and bonuses" is significantly differentiated: this criterion is mentioned four times more frequently in English postings than in French ones. Other significant differences between the postings in the two languages include the criteria "company values" and "reputation", which are more prevalent in the English sample. For the category "organizational assets", mentions in English postings are almost twice as numerous as those in French postings. In addition, more English than French postings highlight criteria in "training and support", notably for the criterion "career path, advancement and growth", but the differences are not significant.

\section{Discussion}

The recent trade literature on business development shows a marked increase in the number of positions available in many sectors and regions worldwide. To date, the practice of this profession has largely exceeded its conceptualization (Eidhoff \& Poelzl, 2014; Fyrpil, 2012). 
Table 2. Requirements mentioned in job postings

\begin{tabular}{|c|c|c|c|c|c|}
\hline & & \multirow{2}{*}{$\begin{array}{l}\text { Total } \\
\text { mentions } \\
\text { in postings } \\
(\mathrm{N}=48) \\
\end{array}$} & \multicolumn{2}{|c|}{$\begin{array}{l}\text { Proportion of job } \\
\text { postings with mention }\end{array}$} & \multirow{2}{*}{$\begin{array}{l}\text { Statistical } \\
\text { significance } \\
\mathrm{Z} \text { test, two } \\
\text { tail, } \mathrm{p} \leq .10\end{array}$} \\
\hline & & & $\begin{array}{l}\text { English } \\
(\mathrm{N}=24)\end{array}$ & $\begin{array}{l}\text { French } \\
(\mathrm{N}=24)\end{array}$ & \\
\hline \multirow[t]{7}{*}{ Experience } & & 103 & & & \\
\hline & Sales & 32 & .563 & .438 & .22 \\
\hline & Sector & 28 & .536 & .464 & .55 \\
\hline & Marketing & 16 & .750 & .250 & .01 \\
\hline & Business development & 13 & .692 & .308 & .10 \\
\hline & Management (team, projects) & 10 & .500 & .500 & -- \\
\hline & Strategy & 4 & .250 & .750 & .29 \\
\hline \multirow{6}{*}{$\begin{array}{l}\text { Technical skills } \\
\text { (Hard skills) }\end{array}$} & & 68 & & & \\
\hline & Total bilingualism (Fr \& En) & 31 & .355 & .645 & .00 \\
\hline & Information systems (MS Office) & 17 & .353 & .647 & .13 \\
\hline & Second language proficiency, oral/written & 9 & .889 & .111 & .00 \\
\hline & Other (finance, technical writing) & 6 & .500 & .500 & -- \\
\hline & Knowledge of more than two languages & 5 & .250 & .750 & .15 \\
\hline \multirow{8}{*}{$\begin{array}{l}\text { General skills } \\
\text { (Soft skills) }\end{array}$} & & 116 & & & \\
\hline & Personality trait & 35 & .629 & .371 & .00 \\
\hline & Interpersonal relations & 26 & .615 & .385 & .08 \\
\hline & Action orientation & 15 & .533 & .467 & .75 \\
\hline & Effective time management & 14 & .500 & .500 & -- \\
\hline & Leadership & 10 & .600 & .400 & .47 \\
\hline & Business culture & 9 & .444 & .556 & .71 \\
\hline & Stress management & 7 & .571 & .429 & .68 \\
\hline \multirow[t]{5}{*}{ Knowledge } & & 101 & & & \\
\hline & Sales/networking & 31 & .484 & .516 & .76 \\
\hline & Communication & 30 & .600 & .400 & .07 \\
\hline & Marketing & 22 & .455 & .545 & .56 \\
\hline & Management & 18 & .389 & .611 & .23 \\
\hline \multirow[t]{8}{*}{ Education required } & & 74 & & & \\
\hline & Bachelor (various) & 22 & .409 & .591 & .24 \\
\hline & Technical/Trade & 15 & .333 & .777 & .11 \\
\hline & No degree mentioned & 14 & .714 & .286 & .05 \\
\hline & Bachelor (Commerce/Business) & 9 & .333 & .667 & .26 \\
\hline & Other degrees & 8 & .750 & .250 & .12 \\
\hline & MBA & 3 & .667 & .333 & .54 \\
\hline & Other master's degrees (various) & 3 & .667 & .333 & .54 \\
\hline \multirow[t]{3}{*}{ Other assets } & & 16 & & & \\
\hline & Travel flexibility & 12 & .500 & .500 & -- \\
\hline & List of contacts & 4 & .750 & .250 & .29 \\
\hline
\end{tabular}

To make up for this lack of knowledge, research has been conducted on two fronts: one group of researchers (Sorensen, 2012; Bussgang et al., 2013) have explored the construct of business development, whereas another stream (Davis \& Sun, 2006; Eidhoff \& Poelzl, 2014) has approached the concept from a practical standpoint by describing the experience of practitioners in this field. By analyzing online job postings and comparing the results with theoretical developments, the present study adopts a combinatory perspective.

We observed that business developers are heavily involved in implementing marketing activities, predominantly as part of the sales process. An important hiring criterion is experience in sales. Desirable candidates must also have personality traits and aptitudes that facilitate interpersonal relations, especially in sales. The role also comprises other aspects of marketing management, namely, in decreasing order of importance, control, planning and analysis. Business developers must therefore be able to contribute to the organization's growth. This is the main finding gleaned from descriptions associated with the criteria pertaining to analysis and planning. In this sense, business development involves more than just sales, even strategic sales. Storbacka et al. (2009) assert that in strategic sales, sales are conceptualized as a process rather than a function, a cross-functional activity rather than an isolated event. 
Table 3. Rewards mentioned in job postings

\begin{tabular}{|c|c|c|c|c|c|}
\hline & & \multirow{2}{*}{$\begin{array}{l}\text { Total } \\
\text { mentions } \\
\text { in postings } \\
(\mathrm{N}=48) \\
\end{array}$} & \multicolumn{2}{|c|}{$\begin{array}{l}\text { Proportion of job } \\
\text { postings with mention }\end{array}$} & \multirow{2}{*}{$\begin{array}{l}\text { Statistical } \\
\text { significance } \\
\mathrm{Z} \text { test, two } \\
\text { tail, } \mathrm{p} \leq .10\end{array}$} \\
\hline & & & $\begin{array}{l}\text { English } \\
(\mathrm{N}=24)\end{array}$ & $\begin{array}{l}\text { French } \\
(\mathrm{N}=24)\end{array}$ & \\
\hline \multirow{5}{*}{$\begin{array}{l}\text { Compensation and } \\
\text { other benefits }\end{array}$} & & 45 & & & \\
\hline & Compensation & 19 & .579 & .421 & .37 \\
\hline & Employee benefits & 13 & .385 & .615 & .33 \\
\hline & Commissions and bonuses & 10 & .800 & .200 & .03 \\
\hline & Discounts on products and services & 3 & .333 & .666 & .54 \\
\hline \multirow[t]{3}{*}{ Training and support } & & 19 & & & \\
\hline & $\begin{array}{l}\text { Career plan, advancement and } \\
\text { development }\end{array}$ & 10 & .700 & .300 & .15 \\
\hline & $\begin{array}{l}\text { Continuous education and skills } \\
\text { development }\end{array}$ & 9 & .556 & .444 & .71 \\
\hline \multirow[t]{5}{*}{ Work environment } & & 53 & & & \\
\hline & $\begin{array}{l}\text { Young, dynamic team, stimulating } \\
\text { challenges to take on }\end{array}$ & 22 & .591 & .409 & .24 \\
\hline & Company values & 18 & .722 & .278 & .01 \\
\hline & Advantages of physical workplace & 10 & .300 & .700 & .15 \\
\hline & Flexible work environment & 3 & .333 & .667 & .54 \\
\hline \multirow{4}{*}{$\begin{array}{l}\text { Organizational } \\
\text { assets }\end{array}$} & & 28 & & & \\
\hline & Reputation & 20 & 650 & .350 & .07 \\
\hline & Noble mission & 4 & .750 & .250 & .29 \\
\hline & Best employer prize & 4 & .750 & .250 & .29 \\
\hline
\end{tabular}

The results of the content analysis tend to confirm that business developers are multitasking professionals who can carry out marketing and sales activities. At the operational level, this entails playing three major roles: 1) identification, analysis, evaluation and selection of business growth opportunities; 2) support for planning, coordination and control in efforts to monetize the value of opportunities retained; and 3) direct and indirect participation in efforts to create partnerships and sales.

To succeed, candidates should hold a technical/trade diploma or an undergraduate degree. Management education is mentioned but is not a priority, nor is a graduate degree (MBA). This result corroborates the findings of Eidhoff \& Poelzl (2014). Surprisingly, several job offers do not mention any degree requirements, but this may be a tactic to attract more applicants. Experience in the sector is important, but specific prior experience in business development is less so, according to the results compiled. Therefore, candidates with a strong set of skills and attributes and who hold a degree, like those mentioned in the results, could certainly have a good chance of being hired. One criterion is indispensable: bilingualism (for French speakers) or knowledge of French as a second language (for English speakers). However, these specific language requirements are idiosyncratic to the population studied.

Regarding incentives or rewards offered, the work environment, reputation of the organization seeking business developers and aspects of pay are very present in the postings. Organizations thus rely on soft "pull factors," increasingly popular among young professionals. Beaudry et al. (2014) report that professional challenges, work climate and ambiance, and work-family balance outweigh the criteria of salary and job security. Increasingly heated competition in markets with practically zero growth is intensifying the hunt for talent. Organizations must obey labor market imperatives regarding incentives. Market orientation is a two-way street, especially when potential applicants have the freedom to choose their employer.

Concerning the impact of language of recruitment work-as a proxy of language of work, on the content of job offers, the results show significant differences for criteria associated with all three of the categories studied. A remarkable significant difference is the reference to sales in the English postings, which is much more prominent than in the French sample. This difference, coupled with that of the "commission and bonus" criterion, even more frequent in the English postings, illustrates the more pronounced weight of sales in the tasks of English-speaking business developers. Commission is a recognized form of compensation for sales people, yet it is mentioned much less often by French-speaking organizations. This pattern can be explained by the concept of 
legitimation, that is the process whereby a practice (a profession in this case) becomes socially, culturally and politically more acceptable (Humphreys, 2010) when "framed" properly. Organizations that do not mention commissions may want to avoid associating their business development jobs too strongly with sales. The lack of this term in French advertisements may indicate a focus on a more modern job description or one that is more acceptable to desirable candidates.

\section{Implications}

For students, employability is a fundamental goal; it represents a return on the investment in their education. Given that qualification mismatch or overeducation can be a concern for business majors ( $\mathrm{Li}$, Malvin, \& Simonson, 2015), careful course selection and deliberate cultivation of essential skills and attributes are paramount. This is also true for academics, whose efforts are rewarded according to the yardstick of their graduates' placement rates and access to higher level positions. Our study informs lets students and academics of the expectations of the labor market for business developers in particular.

For Scheessele (2009), demonstrating learned knowledge of business development thinking is a critical skill. He thus acknowledges the distinctive role of business developers, namely how they must blend sound marketing and sales knowledge to achieve their objectives. Business development is thus an additional tool in the implementation of relationship marketing. Training provided by academics must therefore evolve to satisfy the requirements linked to business developers' central role in networking. Knowledge of the rudiments of internal and external networking is thus essential. Acquisition of soft skills is also deemed central to the success of business developers. Saloner (2010) argues that soft skills are scarce in the work marketplace. These skills are important because they can better differentiate graduates (Muff, 2014).

Academics must also find ways to teach more soft skills; active learning or experiential methods could be part of the solution (Finch, Nadeau, \& O'Reilly, 2012). However, before modifying training programs to better prepare business developers for the job market, academics must also consider the time constraints in most undergraduate business curricula.

The results of the study also have implications for employers. First, companies must be particularly sensitive to the description of roles associated with job postings because expectations differ depending on the culture of the organization. More precise communication of employers' needs will surely facilitate the hiring process, while reducing related time and costs. Employers can also use the results of this research to better grasp the offer of business development jobs, by comparing their postings with those of the competition for the three categories studied. Beyond comparison of working conditions, often limited to the salary aspect, a growing number of employers are incorporating innovative criteria in their postings that reflect the needs of this new generation of job seekers (Beaudry et al., 2014). Because the specialized workforce is rare in several economies, better postings may represent an enduring competitive advantage if they attract ideal candidates.

Lastly, governments around the world are known to invest heavily in education. Administrators of academic institutions that receive budgets are certainly interested in the topic of employability given that a qualified, flexible workforce adapted to the needs of businesses is vital to a prosperous economy. Further, it is increasingly the role of universities to contribute to this virtuous circle, which represents an additional implication of this research.

\section{Limitations}

Although the job search website used in this study (ca.indeed.com) has a general focus, it does not reflect all the jobs available in business development at the time of the study. Organizations of all sizes also use other means of recruitment, which limits the representativeness of the sample retained. Another limitation is the time that the postings were gathered. For practical purposes, we compiled the sample in the summer, which usually corresponds to a slower hiring period.

However, to limit the impact of the collection schedule, we ensured that the postings gathered correspond to different levels in terms of experience and consequently content. Lastly, the fact that the job postings may be incomplete and may not communicate all information on roles, requirements and rewards is another limitation. Postings are not always representative of the actual job situation. The final hiring conditions are often discussed more extensively in the latter stages of hiring, that is during selection interviews and upon signing the employment contract.

\section{Directions for Future Research}

This study examined the case of Québec, but we believe that similar exploratory studies could be conducted in countries that have similar cultural and linguistic conditions, namely where business is carried on in more than 
one official language (Belgium, Switzerland, India), or even unofficial bilingualism (US, for example, with a high to very high concentration of Spanish-speaking citizens in some states). The results of these studies could be useful to produce a general typology of business development roles with clarifications of when the effect of language of work is significant. Not only would such studies extend our research, but they would also build on the findings of Eidhoff \& Poelzl (2014), Davis \& Sun (2006) and Janovics \& Christiansen (2003) regarding employability in business development, and thus increase the generalizability of the results.

Online recruitment advertising in general, and for business developers in particular, is another fertile area of research. For example, future studies could match individuals hired based on online postings with the content of roles for which they are actually responsible in their position. The same exercise could be done for requirements and rewards advertised, to evaluate how well postings attract the best candidates for the positions.

Given that business developers must carry out specific roles related to their position, and engage in internal and external networking with marketing and sales managers, additional research should be done to define the responsibilities of each of these three functions, i.e. marketing, sales and business development, and to put in place interfaces between them. This avenue of research could lead to improved organization of these functions, which could foster integrated commercialization.

Lastly, it is essential to deepen knowledge of business development to guide marketing professors, and thus better meet the needs of organizations seeking these commercialization professionals

\section{Acknowledgments}

The author would like to thank Mss. Anne-Marie Roberge, M.Sc., and Thaïs E. Stephenson-Beaulne, M.Sc Candidate, for their contribution in the content analysis section of the research. He would also like to thank Ms. Florence Lebeau for her comments on the first draft of the paper.

\section{References}

Ahmed, R. I., \& Crossman, J. (2008). Significance of Employability Factors: Bangladesh Perspectives. Journal of Bangladesh Studies, 10(1), 61-66.

Balkin, D. B., \& Gomez-Mejia, L. R. (1987). Toward a Contingency Theory of Compensation Strategy. Strategic Management Journal, 8(2), 169-182. http://dx.doi.org/10.1002/smj.4250080207

Beaudry, C., Laflamme, J., Deschêsne, A. M., \& Aguir, M. (2014). Qu'est-ce qui incitent les finissants universitaires à postuler chez un employeur? Gestion, 38(4), 41-50. http://dx.doi.org/10.3917/riges.384.0041

Boroditsky, L. (2010). Lost in Translation. In J. Bussgang., S. D. Eisenmann, K. Nevins, \& P. Ramani (Eds.), The Business Development Manager. Harvard Business School Note 9-812-107.

Davis, C. H., \& Sun, E. (2006). Business Development Capabilities in Information Technology SMEs in a Regional Economy: An Exploratory Study. Journal of Technology Transfer, 31, 145-161. http://dx.doi.org/10.1007/s10961-005-5027-1

Diamond, K., Pierce, D., Johnson, J., \& Ridley, M. (2014). Content Analysis of Sponsorship Sales Job Postings in the United States. Graduate Journal of Sport, Exercise \& Physical Education Research, 2, 19-36.

Dreher, G. F., \& Cox, Jr. T. H., (1996). Race, Gender, and Opportunity: A Study of Compensation Attainment and the Establishment of Mentoring Relationships. Journal of Applied Psychology, 81(3), 297-308. http://dx.doi.org/10.1037/0021-9010.81.3.297

Eidhoff, A. T., \& Poelzl, J. (2014). Business Development: What's Behind the Name? International Journal of Economics Practices and Theories, 4(5), 835-844.

Erez, M. (2010). Culture and Job Design. Journal of Organizational Behavior, 31, 389-400. http://dx.doi.org/10.1002/job.651

Feldman, D. C., Bearden, W. O., \& Hardesty, D. M. (2006). Varying the Content of Advertisements. Journal of Advertising, 35(1), 123-141. http://dx.doi.org/10.2753/JOA0091-3367350108

Finch, D., Nadeau, J., \& O'Reilly, N. (2012). The Future of Marketing Education: A Practitioner's Perspective. Journal of Marketing Education, 35(1), 54-67. http://dx.doi.org/10.1177/027347531246509

Fyrpil, J. (2012). Business Developer - What's Behind the Title? Retrieved from http://hj.divportal.org/smash/get/diva2:523994/FULLTEXT01.pdf

Giancola, F. L. (2009). Is Total Rewards a Passing Fad? Compensation \& Benefits Review, July-August, 29-35. 
http://dx.doi.org/10.1177/0886368709337926

Gray, S. R., \& Benson, P. G. (2003). Determinants of Executive Compensation in Small Business Development Centers. Nonprofit Management and Leadership, 13, 213-227. http://dx.doi.org/10.1002/nml.11

Harper, S. (2006). PM declares that the Québécois form a nation within a united Canada. Retrieved from http://www.pm.gc.ca/eng/news/2006/11/22/pm-declares-quebecois-form-nationwithin-united-canada

Harvey, L., \& Bowers-Brown, T. (2004). Employability Cross-Country Comparisons. Graduate Market Trends, Winter 2004/5.

Hofstede Center (2014). What about Canada? Retrieved from http://geertHofstede.com/canada.html

Holsti, O. R. (1969). Content Analysis for the Social Sciences and Humanities. Reading, MA: Addison-Wesley.

Hulbert, J. M., Capon, N., \& Piercy, N. F. (2003). Total Integrated Marketing, Breaking the Bounds of the Function. New York, NY: Free Press.

Humphreys, A. (2010). Megamarketing: The Creation of Markets as a Social Process. Journal of Marketing, 74(March), 1-19. http://dx.doi.org/10.1509/jmkg.74.2.1

Jameson, D. A. (2007). Reconceptualizing Cultural Identity and Its Role in Intercultural Business. International Journal of Business Communication, 44(3), 199-235. http://dx.doi.org/10.1177/0021943607301346

Janovics, J. E., \& Christiansen, N. D. (2003). Profiling New Business Development: Personality Correlates of Successful Ideation and Implementation. Social Behavior and Personality, 31(1), 71-80. http://dx.doi.org/10.2224/sbp.2003.31.1.71

Krippendorff, K. (1980). Content Analysis, an Introduction to its Methodology. Beverly Hills, CA: Sage Publications.

LaFleur, E. K., Babin, L. A., \& Lopez, T. B. (2009). Assurance of Learning for Principles of Marketing Students: A Longitudinal Study of a Course-Embedded Direct Assessment. Journal of Marketing Education, 31(2), 131-141. http://dx.doi.org/10.1177/0273475309335242

Lang, K. (1986). A Language Theory of Discrimination. The Quarterly Journal of Economics, 101(2), 363-382. http://dx.doi.org/10.2307/1891120

Li, I., Malvin, M., \& Simonson, R. D. (2015). Overeducation and Employment Mismatch: Wage Penalties for College Degrees in Business. Journal of Education for Business, (away-of-print), 1-8. http://dx.doi.org/10.1080/08832323.2014.988204

Muff, K. (2010). Are Business Schools Doing their Job? Journal of Management Development, 31(7), 648-662. http://dx.doi.org/10.1108/02621711211243854

Pefanis Schlee, R., \& Harich, K. R. (2010). Knowledge and Skill Requirements for MarketingJobs in the $21^{\text {st }}$ Century. Journal of Marketing Education, 32(3), 341-352. http://dx.doi.org/10.1177/0273475310380881

Pollack, S. (2012). What, Exactly, is Business Development? Forbes Magazine. Retrieved from www.forbes.com/sites/scott-pollack/2012/03/21/what-exactly-is-business-development/

Powers, T. L., Jennings, J. C., \& DeCarlo, T. E. (2014). An Assessment of Needed Sales Management Skills. Journal of Personal Selling \& Sales Management, 34(3), 202-222. http://dx.doi.org/10.1080/08853134.2014.890900

Saloner, G. (2010). Building the Next-Generation Business Leader. McKinsey Quarterly, April.

Scheessele, B. (2009). 5 Critical Skills for your Business Developemt Team. Retrieved from http://washingtontechnology.com/articles/2009/08/31/insights-scheessele.aspx

Schuler, R. S., \& Rogovsky, N. (1998). Understanding Compensation Practice Variations across Firms: The Impact of National Culture. Journal of International Business Studies, 29(1), 159-177. http://dx.doi.org/10.1057/palgrave.jibs. 8490030

Shoemaker, P. J. (2003). Intercoder Reliability. Retrieved from http://22024930INTERCODER RELIABILITY

Sorenen, H. E. (2012). Business Development, A Market-Oriented Perspective. West Sussex, UK: Wiley.

Sorensen, H. E. (2014). Business Development: Measurement and Performance. In E. Bigné (Ed.), Proceedings of the $43^{\text {rd }}$ EMAC Annual Conference, Paradigm Shifts \& Interactions. Valencia, Spain.

Storbacka, K., Ryals, L., Davies, I. A., \& Nenonen, S. (2009). The Changing Role of Sales: Viewing sales as a 
Strategic, Cross-Functional Process. European Journal of Marketing, 43(7/8), 890-906. http://dx.doi.org/10.1108/03090560910961443

Wildavsky, B. (2010). The Great Brain Race: How Global Universities Are Reshaping the World. Princeton, NJ: Princeton University Press.

\section{Copyrights}

Copyright for this article is retained by the author, with first publication rights granted to the journal.

This is an open-access article distributed under the terms and conditions of the Creative Commons Attribution license (http://creativecommons.org/licenses/by/3.0/) 